was advised not to "cover" a "specialist midwife" who was proposing to insert IUCDs as part of the domiciliary service provided by the local branch of the Family Planning Association. I presume the same advice would still be given. I do not think that nurses should be allowed to insert IUCDs as the complications which inevitably arise might bring this valuable method of contraception into disrepute.

T G E WhITE

Croydon, Surrey

\section{Antibiotics again}

SIR,-Your leading article (8 May, $p$ 1107) disapproves of the fact "that chloramphenicol continues to be prescribed for illnesses othe than typhoid fever." If this remark discourages use of chloramphenicol in haemophilus meningitis and other life-threatening infections due to Haemophilus influenzae Type $\mathrm{b}$ it could have serious consequences.

In their 1967 leaflet about chloramphenicol the Committee on Safety of Drugs stated: "It is a highly effective drug in typhoid fever and in $H$. influenzae meningitis. In these conditions its advantages outweigh its dangers." Since then the case for using ampicillin (the only serious alternative to chloramphenicol) for treatment of haemophilus meningitis has been weakened by reports of its failure to eradicate the infection in some cases despite normal ampicillin sensitivity of the organism ${ }^{1}$, of more rapid resolution of signs of infection when chloramphenicol is used ${ }^{2}$; and of cases of meningitis due to $\beta$-lactamase-producing (and therefore ampicillin-resistant) strains of $H$ influenzae. ${ }^{3}$

I hope to publish soon laboratory data supporting the suggestion that chloramphenicol is more effective than ampicillin against $H$ influenzae Type $\mathrm{b}$ in circumstances which may well be relevant to conditions in the meninges in haemophilus meningitis. Available information suggests that children with haemophilus meningitis and similar severe haemophilus infections who are given ampicillin rather than chloramphenicol may not improve as rapidly as they should, may relapse, or may (if they are unfortunate enough to have an ampicillin-resistant haemophilus) die from lack of effective treatment. In these circumstances I must sharply disagree with the reprimand implied in your leading article.

\section{C TURK}

Bacteriology Department, Gibson Laboratories, Radcliffe Infirmary,
Oxford

${ }^{1}$ Kandall, S R, Davis, T C, and Abramowicz, M, Clinical Pediatrics, 1972, 11, 264.

2 Shackelford, P G, et al, New England fournal of Medicine, 1972, 287, 634 .

${ }^{3}$ Nelson, J D, fournal of the American Medical Association, 1974, 229, 322.

\section{Devolution}

SIR,-As a prospective Plaid Cymru parliamentary candidate I found that the transcript of your conference on devolution (8 May, $p$ 1127) brought out some very interesting points.

Relating specifically to medicine, there are two points I would like to emphasise. Firstly, the medical service in Wales, in common with many parts of England, is grossly over- dependent on medical staff from other countries. Any suggestion that we could not plan our health service better than at present is quite laughable when one considers that our own doctors are frequently in a minority in our own hospitals. Such a situation would be except possibly in the Third World, and then it would undoubtedly only be on a temporary basis. I have greater faith in the ability of the medical world in Wales to plan for this relatively small country in a more efficient manner and with greater foresight than the Elephant and Castle has done for the UK in the past and to develop such a service without constant political interference.

The other point I would wish to lay before the doubters of devolution is the importan one of pay differentials arising in a devolved UK. My only comment here is that I should hope they would. Ironically, in General Practitioner the same week as the seminar it was shown that general practitioners in the UK are now the poorest in Europe. Even Ireland is apparently now in a position to offer medical staff a better deal than in the UK. Service than they are at present. There is a lack of confidence which I have not experienced previously and which I believe will be righted only as and when we have devolution and a system of government which is readily answerable to the people it serves. A self-governing Wales with its rightful priorities would indeed not only benefit Wales but help England to find its true role as a partner in Europe. A recent decision of the London Government, for example, to invest in 600 new multirole combat aircraft, despite our economic prolems, at an average cost of $£ 5 \mathrm{~m}$ each smacks of imperialistic grandiosity. That age is gone if for no other reason than that the UK cannot afford such priorities, and I am convinced that this is the opinion of the vast majority of the English people too.

In the Western developed world many of our social problems arise through a lack of identity and rootlessness. In Wales particularly there is a very rich tradition of community. This can be enhanced only by relating this tradition to the ideal of full nationhood status for our country.

Of one thing we can be certain: the next five years will be very exciting ones for our respective countries.

Carl Iwan Clowes Gwynedd

SIR,-Your discussion of devolution (8 May, p 1127) contained data on the under-financing and under-staffing of English hospitals which look even more remarkable on recalculation per caput. quite unacceptable in any other country

Things could hardly be worse in the Health
Per head of population Scotland in 1973-4 compared with England had $17 \%$ more family doctors, $23 \%$ more nurses and midwives, and $54 \%$ more hospital doctors, and this year each Scot is to be allowed $23 \%$ more money on total health services than each Englishman.

J H BARON

London NW8

Oestrogens as a cause of endometrial carcinoma

SIR,-We have read your leading article (3 April, p 791) and related correspondence with considerable interest, for, like many other gynaecologists who were initially conservative towards oestrogen replacement therapy, we have come to appreciate the benefits that can be afforded to patients with climacteric and post-menopausal disturbances and have become "moderates," supporting some symptomatic therapy. Like other clinicians we have also been perturbed by the reports ${ }^{12}$ from America suggesting that such therapy might be associated with an increased risk of endometrial carcinoma and have noted the criticisms of these studies by $\mathrm{Mr} \mathrm{J} \mathrm{W} \mathrm{W} \mathrm{Studd} \mathrm{(8} \mathrm{May,}$ p 1144). His comments relating to the retrospective nature of these reports and the need for an independent review of the relevant histology seem particularly apposite. With regard to inadequate socioeconomic matching being a confounding factor, however, in the series of Ziel and Finkle ${ }^{2}$ patients and controls were matched for areas of residence and one wonders therefore whether such socioeconomic groupings in this report were that unbalanced.

We note the reservations in your leading article on the value of administering progestational compounds with oestrogen therapy in hormone replacement regimens, but the results of treatment of persistent endometrial hyperplasia with progestogens by such authorities as Wentz, ${ }^{3}$ Kistner, ${ }^{45}$ and Taylor $^{6}$ and their effectiveness in causing regression of an endometrial state that many authorities believe antedates uterine carcinoma make the concomitant use of progestogens a very pertinent consideration. The observations of $\mathrm{Dr} \mathrm{E}$ Schleyer-Saunders (8 May, p 1145) give further support to the adoption of an oestrogenprogestogen regimen and a sequential form of replacement therapy has been commonly favoured by $\mathrm{Mr} \mathrm{Studd}{ }^{7}$ and other authorities.

The need for continued vigilance even with an oestrogen-progestogen mode of treatment nevertheless is emphasised by a small number of cases of endometrial carcinoma reported in patients taking oral contraceptives of both the sequential and combined forms. ${ }^{8}{ }^{9}$ It has been postulated that such patients may have localised "islands" of endometrium refractory to

\begin{tabular}{|c|c|c|c|c|}
\hline & England & Wales & Scotland & $\begin{array}{c}\text { Excess, } \\
\text { Scotland } v \text { England }\end{array}$ \\
\hline 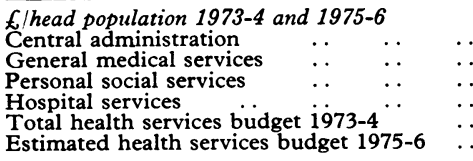 & $\begin{array}{l}0 \cdot 45 \\
4 \cdot 05 \\
10 \cdot 2 \\
36 \cdot 6 \\
65 \cdot 3 \\
79\end{array}$ & $\begin{array}{l}0.41 \\
4 \cdot 1 \\
8.9 \\
36.4 \\
56 \cdot 4 \\
82\end{array}$ & $\begin{array}{l}0 \cdot 44 \\
4 \cdot 4 \\
7 \cdot 6 \\
46.9 \\
65 \cdot 6 \\
97\end{array}$ & $\begin{array}{l}-2 \% \\
+9 \% \\
-25 \% \\
+28 \% \\
+1 \% \\
+23 \%\end{array}$ \\
\hline $\begin{array}{l}\text { Health Services Staff per million population } \\
\text { Hopsital doctors } \\
\text { GPs (including assistants and trainees) } \\
\text { Community physicians } \\
\text { Hospital nursing and midwifery } \\
\text { Hos }\end{array}$ & $\begin{array}{r}551 \\
485 \\
28 \\
6869\end{array}$ & $\begin{array}{r}521 \\
490 \\
98 \\
6385\end{array}$ & $\begin{array}{r}848 \\
568 \\
59 \\
8483\end{array}$ & $\begin{array}{l}+54 \% \\
+17 \% \\
+110 \% \\
+23 \%\end{array}$ \\
\hline
\end{tabular}


the progestogen component and reactive only to oestrogen, the unopposed oestrogenic stimulus on such foci subsequently leading to the development of endometrial carcinoma. ${ }^{9}$

\section{R CORCORAN}

R HOWARD

St Catherine's Hospital,

Smith, D C, et al, New England fournal of Medicine, 1975, 293, 1164 .

Ziel, H K, and Finkle, W D, New England fournal of Medicine, 1975, 293, 1167

Wentz, W B, American fournal of Obstetrics and Kynecology, 1966, 96, 999

stner, $\mathrm{R}$, International fournal of Obstetrics and Gynaecology (Part 2), 1970, 8, 561.
Kistner, R W, in Endocrine Therapy

istner, R Walignant Disease, ed B A Stoll, p 313. Philadelphia, Saunders, aylor, C W, in Modern Trends in Gynaecology, e R J Kellar, p 132. London, Butterworths, 1969 Studd, J W W, Current Medical Research and Opinion, 1975,3 , suppl 3, p 60

Gynecology, 1975, 46, 503. Obstetric Pathology, p 211. Philadelphia Saunders, 1974.

\section{Laparoscopy explosion hazards with nitrous oxide}

SIR,-We apologise for the delay in replying to the letter of Drs G B Drummond and D B Scott (6 March, p 586), which was caused by illness.

We find ourselves in agreement with $\mathrm{Mr}$ P C Steptoe (3 April, p 833) concerning the inadequacies of the measurements made by Drs Drummond and Scott and especially concerning the justification of their conclusions. We regret the lack of experimental detail about the sampling, analysis, and calibration procedures used, which prevents any assessment being made of the validity of their work.

That hydrogen, in a standard mixture with methane and nitrogen, could be stored in a greased glass syringe closed with a polyethylene tap for 10 days, or even two days, without any significant loss was very surprising to us because of the well-documented high diffusion coefficients in most materials, including lubricants and polymers. In fact, we would have expected no loss to have occurred during storage only if the mixture had been stored over mercury in a thick-walled glass container. During recent attempts to analyse intestinal gas we found that the results were quite unreliable unless the samples were analysed within four hours, using a scanning mass spectrometer. Without the experimental figures we are unconvinced by the claims of Drs Drummond and Scott about hydrogen losses and consequently sceptical about their values for hydrogen concentration in their samples.

However, we must agree with Mr Steptoe that samples from 12 laparoscopies is a small number and especially that nitrous oxide usage is likely to be dangerous when bowe puncture occurs (at least $2^{\circ}{ }_{0}$ of cases according to $\mathrm{Mr}$ Steptoe) using high-frequency electric diathermy. Similar criticisms about the num bers of cases reported by Drs S Khunda and K Y Ghanima (8 May, p 1147) can be made (28 cases using diathermy).

JOHN S ROBINSON JOHN M THOMPSON A W WOOD
The community physician of the future

SIR,-Your editorial description (24 April, p 976) of the training of the community physician of the future carries the extraordinary assumption that his or her postgraduate education is available only in England. No mention is made of what goes on in the four Scottish medical schools, which are playing, as they have done for 50 years or more, a very considerable role in the new venture of community medicine no less than in the older discipline of public health.

Since the $B M F$ is British and since Scotland, thank goodness, is still part of Britain I had hoped that someone closer to London than I would by this time have corrected the uncharacteristic discourtesy and inaccuracy in your editorial columns. In writing now, however, I can testify to the pleasure with which we welcome in our training programmes many applicants from England as well as from Commonwealth and other countries and express the hope that they will not assume from your article that we are no longer in business.

May I also while writing suggest that you are asking too much when you urge the community physician to acquire an MRCP or MRCGP as well as an MFCM ? What is needed-and the need is widely felt-is a common primary as a test of basic knowledge, including epidemiology and biometrics, before admission to membership of any of the col leges. In this way medicine might begin to reintegrate itself, in which case the unfortunate lapse in your columns will serve such a useful purpose that no apology is needed.

GORDON T STEWART

Department of Community Medicine,

University of Glasgow

\section{Failure of phenobarbitone to prevent} febrile convulsions

SIR,-The article by Dr J Z Heckmatt and others (6 March, p 559) contains, we believe, both misleading conclusions and faulty reasoning.

The recurrence rate of febrile convulsions was $8 \cdot 2^{\circ}{ }_{0}$ in the group treated with continuou phenobarbitone and $19.2^{\circ}$, in the contro group, with an observation period of six months. A reduction in recurrence rate to $43^{\circ}$ " of that in the controls appears clinically important but is not statistically significan when one uses a two-tail test at the $5^{\circ}$ level When one sees what may be a clinically important effect which does not attain statistical significance it would seem inappropriate to declare this as proof of no treatment effect. If the same rates of recurrence were to prevail the results would have been declared sig nificant with only 26 additional subjects in each group. With the observed rates the results would also have been significant if all 88 subjects in the phenobarbitone-treated group had satisfactorily completed the trial. Thus the authors were not far from reaching conclusion opposite to that claimed in the title of their paper. It is interesting to note that if their present data are tested with only one tail they are significant at the $5 \%$ level.

The authors argue that the recurrence of febrile convulsions in some children whose phenobarbitone levels are in the therapeutic range proves the ineffectiveness of this drug.
We disagree and think that this proves only that some children may not be protected against febrile seizure recurrences by levels of phenobarbitone ordinarily considered adequate but that many other children may be protected.

Finally, there are four recent studies, ${ }^{1-4}$ including our own (which is randomised and prospective with a concurrent control group), which do show the effectiveness of daily phenobarbitone in the prevention of febrile seizure recurrences.

Department of Neurology,

Southern California Permanente

SHELdON M Wolf Medical Group

Alan B Forsythe

Department of Biomathematics,

University of California,

Los Angeles

Faero, O, et al, Epilepsia, 1972, 13, 279

Thorn, I, Acta Neurologica Scandinavica, 1975

Wallace, S, Acta Neurologica Scandinavica, 1975,

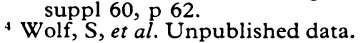

**We sent a copy of this letter to Dr Heckmatt and his colleagues, whose reply is printed below.-ED, $B M \mathcal{}$.

SIR,-We are grateful for the opportunity to reply to Drs Wolf and Forsythe, but cannot accept that our paper was misleading either in title or conclusions.

After the publication by Faero et al many authors, in particular Lennox-Buchthal, wrote and lectured that phenobarbitone if given in sufficient dosage to keep a certain blood concentration $(65: \mathrm{mol}(15 \mathrm{mg}) / 1)$ would prevent febrile convulsions recurring. This would have been important for anxious parents in each succeeding fever because prevention was given its usual meaning: to preclude, to stop, keep or hinder effectually, to keep from coming to pass. In such a way prophylactic appendicectomy prevents appendicitis in the mountaineer or polar explorer. In this sense we have shown that phenobarbitone at the recommended blood level does not prevent febrile convulsions. In fact Thorn ${ }^{3}$ found the same in her study: four of the recurrences were in children with phenobarbitone blood levels of above $65: \mathrm{mol}(15 \mathrm{mg}) / \mathrm{l}$ at the time of the convulsion.

The suggestion that a statistically insignificant reduction in recurrence rate would become significant with increased numbers is dangerous on two grounds. The first is illustrated by an experiment in which there was an insignificant excess of heads after a series of coin tosses. ${ }^{4}$ The argument of Drs Wolf and Forsythe would have it that if the same rates of recurrence were to prevail a larger number of tosses would show that the coin was biased to fall down heads.

The second objection relates to the suggested inclusion for statistical purposes of those who did not satisfactorily complete the trial. Half of these (18\% of those offered treatment) stopped the treatment because the family could not tolerate the side effects. In identical manner Thorn ${ }^{3}$ found that $21 \%$ had to discontinue phenobarbitone because of side effects.

If phenobarbitone does not prevent febrile convulsions but reduces the incidence (as Wallace ${ }^{5}$ and Thorn $^{3}$ have suggested) then one would expect a kind of dose-response curve-the higher the blood level, the lowes 